\title{
legelivet,
}

På disse sidene i Tidsskriftet - legelivet - finner du stoff om legers liv.

Her er det presentasjon av arbeidssteder, nyhetssaker, nye doktorgrader,

nye spesialister og minneord. Alt samlet på ett sted - så du kan følge enda bedre med.

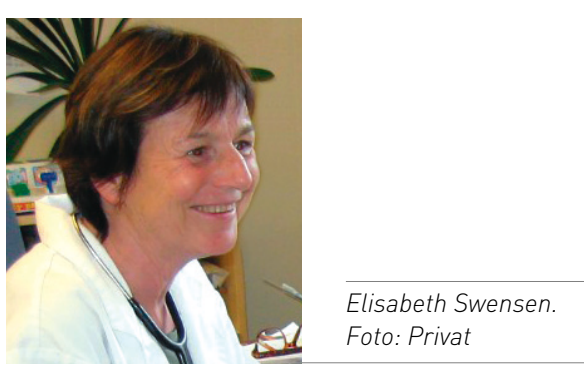

Elisabeth Swensen (f. 1951) er kommuneoverlege og fastlege ved Seljord helsesenter.

\section{Når angsten eter sjelen}

Leger bærer et stort personlig ansvar. Det krever at man holder angsten i sjakk, men også i hevd.

I fjor hadde legetjenesten vår besøk av Arbeidstilsynet. Besøket avfødte en interessant og prinsipiell diskusjon mellom tilsynet og legene om forskjellen på et premiss og et arbeidsmiljøproblem. Legene innrømmet, i henhold til malen for tilsynet, å være utsatt for «psykososialt stress». Samtidig fastholdt vi at dette ligger implisitt, som en forutsetning, i oppdraget vi har tatt på oss og lønnes godt for.

Rollen som garantist for andres trygghet og sikkerhet gikk for alvor opp for meg på mine første legevakter i Vest-Telemark. Som turnuslege ved Notodden sykehus hadde jeg i det minste hatt en levende bakvakt, en overlege av kjøtt og blod, riktignok hjemme og i varierende utrykningsmodus, men allikevel. Alene på vakt, uendelig langt fra sykehus, utstyrt med nyinnkjøpt legekoffert og ditto bil, ble distriktsturnus selve lakmustesten på faglig mot og evne til kognitiv egenterapi. Det verste var å sitte hjemme og stirre på en taus telefon mens man ventet på det forferdelige. Det beste var de første erfaringene av å mestre nettopp det forferdelige når det en sjelden gang inntraff. Dette var på den tiden små barn fortsatt fikk eksempelvis epiglotitt. AMK var ikke oppfunnet, og ambulansen var i praksis en varebil med båre og litt elementært utstyr i bakrommet og en hyggelig sjåfør som også drev bygdas bensinstasjon.
Jeg ble aldri glad i akuttmedisinen, selv om det i korte glimt kunne være morsomt å kjenne seg som heltinne. Og jeg sluttet aldri å kjenne på det som best kan beskrives som et «uhensiktsmessig indre beredskapsnivå» når jeg hadde vakt. Likevel - eller nettopp derfor - er jeg glad for at legevakt har vært en uunngåelig del av jobben. Læring er uløselig knyttet til et visst ubehag. Tenk bare på et barn som tar sine første skritt. Reise seg og falle, igjen og igjen. Å takle sin egen angst samtidig som man inngir trygghet hos pasienten og omgivelsene er en del av kjernekompetansen som lege. Antakelig er angsten også med på å holde oss skjerpet, slik skuespillere sier at de blir nervøse hvis de ikke kjenner på nervøsiteten rett før de skal på scenen.

Hvert halvår holder legevakten og ambulansetjenesten i Seljord introduksjonskurs i akuttmedisin for de nye distriktsturnuslegene i fylket før de får lov til å ha legevakt. Jeg starter alltid med å spørre hvor mange som er redde før de skal ut i den uselekterte virkeligheten der alt kan skje. Nesten alle rekker opp hånden. Det er betryggende.

\section{Elisabeth Swensen}

elswense@online.no 